\title{
A SIX-COUNTRY COMPARISON OF THE INTERNET SHOPPER PROFILE
}

\author{
Thomas G. Brashear' \\ Vishal Kashyap² \\ Michael D. Musante ${ }^{3}$ \\ Naveen Donthu ${ }^{4}$
}

\begin{abstract}
As the Internet continues to evolve across the globe, the importance of understanding the similarities and dissimilarities among consumers in different regions is crucial for bothe marketing theory and practice. The authors report the characteristics of Internet shoppers in six countries (United States, England, New Zealand, China, Brazil, and Bulgaria). Internet shoppers and non-shoppers in these countries are profiled and compared on attitudes, motivations, and demographics. The work extends the research of Donthu and Garcia (1999) into an international realm and seeks to build on our current knowledge in this area. Findings show that online shoppers share many similar traits around the world. Internet shoppers in all the countries examined are similar with regard to their desire for convenience, are more impulsive, have more favorable attitudes towards direct marketing and advertising, are wealthier and are heavier users of both email and the Internet.
\end{abstract}

Keywords: Internet shoppers and non-shoppers. Direct marketing and advertising. Attitudinal and Motivational Dimensions

\section{INTRODUCTION}

In the last decade the Internet has moved from being a novel technology to a routine channel for information, communication, and retail/shopping. As a retail

\footnotetext{
'Associate Professor of Marketing, Eugene M. Isenberg School of Management, University of Massachusetts. Amherst. I 2 I Presidents Drive, Amherst, MA 0 003.E-mail: brashear@mktg.umass.edu.

${ }^{2}$ Assistant Professor of Marketing, Williams College of Business, Xavier University, Cincinnati, Ohio 45207. E-mail: kashyapv@ xavier.edu.

${ }^{3}$ Assistant Professor of Marketing, School of Business, Quinnipiac University 275 Mount Carmel Ave. Hamden, CT 065 I 8. E-mail: michael.musante@quinnipiac.edu

${ }^{4}$ Katherine S. Bernhardt Research Professor, Department of Marketing, J. Mack Robinson College of Business, Georgia State University. Atlanta, GA 30303. E-mail: ndonthu@gsu.edu. Artigo Recebido em: 28/07/2007. Aceito em: 07/08/2008. Membro do Corpo Editorial Científico responsável pelo processo editorial: Prof. Emerson Antônio Maccari.
} 
channel, the Internet has not yet reached the mainstream status of its in-store counterparts (SOOPRAMANIEN; ROBERTSON, 2006), however business and researchers remain interested in the way consumers will continue to use the Internet (e.g. ROHM; SWAMINATHAN, 2004). The growth in online shopping and the continuing movement of retailers to a multi-channel format imply that this medium will continue to grow in importance but a non-U.S. centric view of Internet usage and shopping behavior in particular needs to be addressed. As an example, European and Asian online shoppers average almost twice as many purchases as North American online shoppers and growth in online shopping is faster in the developing markets than the developed economies (AC NIELSEN, 2005). Total ecommerce sales in Japan, South Korea, China, India were US\$51 million in 2006, and expected to grow to US\$115 billion in 2010 (EMARKETER, 2007).

Growth in Internet usage and e-commerce is expected to come from regions outside the U.S. with current world Internet usage estimated to be over one billion users (INTERNETWORLDSTATS, 2006). While the growth rate in Internet usage worldwide between the years 2000 and 2007 has been over $200 \%$, Internet penetration statistics reveal that most of the regions in the world still offer opportunity for substantial growth. The Computer Industry Almanac (2006) predicts that the global Internet population is expected to grow to almost 2 billion by 2010 . In response to these trends, companies need to globalize their e-business to generate increased business value since a global virtual presence can be more feasible and less expensive than a physical presence (MAHMOOD; BAGCHI; FORD, 2004). To that end, an initial step is to understand the differences between Internet shoppers and non-shoppers globally. The knowledge and assessment of the commonalities and unique characteristics between online consumers in different markets is both timely and important. Of the over 200 million active Internet users in the U.S., only 33\% report actually making a purchase on the Internet (BUSINESSWEEK 2006). However, limited research in marketing addresses how Internet users and shoppers differ across the globe. Such research is important given that a majority of the growth in e-commerce is expected to come from regions outside of the U.S.

Prior research that has explored the Internet shopper in a global context has looked at shoppers within specific countries. The profile of the typical Internet shopper in the U.S. has been well defined by Donthu and Garcia (1999). Other individual, non comparative studies have been conducted in Germany (e.g. PECHTL, 2003), Hong Kong (e.g. KOLSAKER; LEE KELLEY; PUI, 2004). Additionally, structural elements such as website characteristics and quality (e.g. KIM; LEE 2006; LYNCH; KENT; SRINIVASAN, 2001) have been the focus of research. The extant research that explores multiple countries primarily does so from a cultural perspective by incorporating variables such as uncertainty avoidance and individualism - collec- 
tivism (e.g. PARK; JUN, 2003) with notable exceptions (LYNCH; BECK, 2001). Knowledge and assessment of the commonalities and unique characteristics between online consumers in different markets is both timely and important.

The objective of the study is to contribute to our understanding of the differences between Internet users and online shoppers. Of particular interest is whether the characteristics and profiles of the Internet shopper differ across regions or markets. In this research effort, we look beyond demographics to also focus on the attitudes and motivations that make these shoppers unique. This research responds to the call for exploring online consumers across the world (DONTHU; GARCIA, 1999; KORGAONKAR; WOLIN, 1999). In doing so our research extends the work of Donthu and Garcia (1999) into an international realm.

The rest of the paper is organized as follows. In the next section, we review the relevant literature and formulate the hypotheses for the study. This is followed by a section on the methodology of our study. We then expand on and discuss the results of our study. We follow by elaborating on the theoretical and managerial implications of our results. Finally, we conclude with a section on the limitations and future research possibilities of our study.

\section{LITERATURE REVIEW AND HYPOTHESES DEVELOPMENT}

\subsection{Internet Shoppers Versus Non-shoppers}

As Internet usage increases worldwide, one can expect to see a concomitant rise in the use of this interactive tool in consumers' shopping decisions. More importantly, it becomes crucial to distinguish between those who use the Internet as a shopping tool as opposed to those who do not. This is because prior research finds that browsers, or Internet users, can be behaviorally different from buyers, i.e. those who shop on the Internet (SOOPRAMANIEN; ROBERTSON, 2007). Donthu and Garcia (1999) also find that the typical Internet user differs from the Internet shopper in the U.S. We define Internet "shoppers" as those users of the Internet who make purchases online. All other Internet users are "non-shoppers". Internet use is not a direct correlate of Internet shopping or purchasing. In an effort to understand more about the Internet shopper segment, we focus on various attitudinal, motivational, and demographic characteristics of Internet shoppers and non-shoppers across 6 countries. Our work helps to shed light on the similarities and differences of this segment in these countries.

The pattern of Internet users and shoppers varies by country and region. For example, in the United States, 74\% of all users use the Internet as a shopping search tool, and approximately $33 \%$ of all users buy online (BUSINESSWEEK, 2006). In the Asia Pacific region, Australians and New Zealanders are the most likely to use 
the Internet to seek information about products and services (estimated at 25\%). Online purchasing is far more common in Australia and New Zealand, and South Korea, than in Hong Kong, Taiwan and Singapore. Whereas 63 percent of Europe's population was estimated to be online in 2007 and 37 percent of this group shopping on the Internet, European browsing and purchasing patterns vary country to country (DELLNER, 2007). Two out of three Internet users in Germany buy online (GERMANY: ONLINE OVERVIEW; EMARKETER, 2007). High levels of Internet usage has typically been the most often used indicator of a potential cybershopper (MOE; FADER, 2001). In Brazil, 40 percent of Internet users have made purchases online (DATAFOLHA, 2005). However, heavy Internet usage need not necessarily translate into frequent online shopping, especially internationally. Prior research finds that the heavy users of the Internet for personal uses are believed to be younger, less educated, and lower in income (KORGOANKAR; WOLIN, 1999). This is particularly true for emerging markets where a majority of Internet users are very young. Forty six percent of China's 30 million estimated Internet users are between 18 and 24 (SHANGHAI DAILY, 2001). Therefore to target heavy users alone may be a flawed strategy as all users may not necessarily be Internet shoppers. A consideration of demographic characteristics alone in targeting Internet shoppers can therefore be detrimental to the growth of an effective Internet strategy. Attitudes and motivational dimensions are thus an important component of an effective marketing strategy when targeting the Internet shopper.

\subsection{Attitudinal and Motivational Dimensions}

In order to fully understand the existing segments that exist in the U.S. market, Donthu and Garcia (1999) conducted a broad study to study the profiles of Internet shoppers and non-shoppers along various demographic, attitudinal and motivational dimensions. They found that U.S. Internet shoppers were older and had higher incomes than non-shoppers. Internet shoppers were also more likely to be convenience seeking, innovative, less risk averse and impulsive than non-shoppers. These types of attitudinal and motivational elements have been used across the literature to profile in-home shoppers, recreational shoppers, and infomercial shoppers with the objective of providing a broader profile of shoppers and differentiating shoppers and non-shoppers in the various shopping genres. The goal of this study is to extend this research into global Internet shoppers and non-shoppers. In this analysis, we develop and examine the hypotheses tested by Donthu and Garcia (1999) with respect to a global perspective. The dimensions examined in this analysis include convenience, innovativeness, risk aversion, variety seeking behavior, impulsiveness, brand consciousness, and price consciousness. 


\section{Convenience}

Similar to other direct shopping methods, using the Internet to shop is associated with convenience. In-home shoppers enjoy multiple forms of convenience according to Darian (1987). They include less shopping time, flexibility with regard to when they shop, less physical effort, and easier response to advertising or promotions. Similarly, Eastlick and Feinberg's (1999) study of catalog shoppers found that convenience was based on consumers finding what they want in short time period, with less effort, and any time of day shopping. Girard, Korgaonkar, and Silverblatt (2003) found that convenience was one of the highest attractions to shopping online. Rohm and Swaminathan (2004) found convenience to be a centerpiece when assessing shopper motivations. Therefore we propose:

$\mathbf{H}_{1}$ : Internet shoppers are more convenience seeking than non-shoppers. Innovativeness

Innovativeness is the relative willingness of a person to try a new product or service (GOLDSMITH; HOFACKER, 1991). Following the rationale of Donthu and Garcia (1999), innovativeness was a key attribute of the online shopper segments of Actualizers and Experiencers (SRI International, 1995). Actualizers as a consumer segment are active, very discriminating in their purchases, and also rather adventurous in their activities. Experiencers are innovative and modern, seek stimulation, and are also considered trend setting or fashionable (SRI International, 1995). Donthu and Garcia (1999) found empirically that online shoppers were more innovative than non-shoppers. Another study by Goldsmith and Flynn (2004) looked at a specific type of online purchasing (clothing), and found that innovativeness was a significant predictor of online consumption. Therefore, we predict that:

$\mathbf{H}_{2}$ : Internet shoppers report more innovative behavior than non-shoppers. Risk Aversion

Shopping on the Internet has been associated with carrying risk. In particular, privacy related concerns, identity and credit card theft, and lack of order fulfillment (or order errors) have all been noted concerns (DUBELAAR; JEVONS; PARKER, 2003). Ease of product returns also troubles some shoppers. All of these issues increase risk, and subsequently influence the decision to shop online. Donthu and Garcia (1999) predicted that online shoppers would have lower levels of risk aversion and this was supported. Others have noted that shoppers are less worried about risks of financial loss than non-shoppers (ALLRED; SMITH; SWINYARD, 2006). There is also research to support the premise that risk tolerance is a common theme globally. In a study in Singapore, Tan (1999) found that online shoppers had much lower levels of risk aversion than non-shoppers. Doolin et al. (2005) in a study in New Zealand, found that risk tolerance was a strong predictor of online shopping and the level of repeat shopping. Given this, the following is predicted: 
$\mathbf{H}_{3:}$ Internet shoppers are lower in risk aversion than non-shoppers. Variety Seeking

Variety Seeking has been defined as the alternation among products or brands over a series of choices (KAHN; ISEN, 1993). Some consumers who are variety seekers alternate between brands and products even tough their most preferred selection is available (RATNER; KAHN; KAHNEMAN, 1999; RATNER; KAHN, 2002). Given the ease of Internet search versus traditional search, it follows that online shoppers would search more extensively than their offline counterparts. Such search would lend itself to variety seeking behavior. In their effort to form a typology of the Internet shopper, Rohm and Swaminathan (2004), characterized four types of Internet shoppers, one of which they identified as variety seekers. They found that the variety seeker is substantially more motivated by variety seeking across retail alternatives and product types and brands than any other shopping type. Donthu and Garcia (1999) found that, in general, online shoppers had higher levels of variety seeking than non-shoppers. This is consistent with other tendencies of the online shopper including their recreational nature and their risk aversion. Thus we submit that:

$\mathbf{H}_{4:}$ Internet shoppers will be more variety seekers than non-shoppers. Impulsiveness

The consumer behavior literature refers to impulse buying as extraordinary, emotion-saturated buying that takes place largely without regard to financial or other consequences (WOOD, 2005). Hoffman and Novak (1997) found that heavy Internet users, including shoppers, get into "a flow" on the Web. They become very involved with the process and it becomes synonymous to a recreational experience (DONTHU; GARCIA, 1999). Recreational shoppers are less traditional, tend to be more innovative, are information seekers, and are prone to making more impulsive purchases (BELLENGER; KORGAONKAR, 1980). Similarly, Darian (1987) proposed that in-home shoppers were more impulsive. Donthu and Garcia (1999) found that online shoppers scored higher on measures of impulsiveness than did non-shoppers. Zhang, Prybutok, and Koh (2006) suggest that there exists a positive relationship between consumer impulsiveness and online purchasing behavior. Conversely, Girard, Korgaonkar, and Silverblatt (2003) characterized online shoppers as being high on the recreational shopping scale but did not find a direct link with impulsiveness. However, this may be due to the collinear effects of the variables. Given the previous work, the following hypothesis is proposed:

$\mathbf{H}_{5:}$ Internet shoppers will have higher levels of impulsiveness than non-shoppers.

\section{Brand Consciousness}

Brand consciousness is a shopping orientation, which is characterized by the degree to which a consumer is oriented towards buying well known branded prod- 
ucts (SHIM; GEHRT, 1996; SPROLES; KENDALL, 1986). In-flight shoppers have also been shown to have higher levels of brand consciousness (HUANGA; LIANG KUAIB, 2006). Donthu and Garcia (1999) suggest that the major forces on the Internet who are selling products to consumers are well-established and well-known companies. These companies tend to have very high brand recognition. Research suggests that high brand recognition will lower the risk to the consumer when purchasing online (TAN, 1999). As a result individuals will feel more reassured purchasing online if they are buying from an entity with a name they know and trust. While Donthu and Garcia (1999) did not find this to be a significant factor, Park and Stoel (2005) did find that brand familiarity increases the likelihood to make an online purchase. Likewise, Seo (2005) finds that Internet purchasers tend to have high levels of brand involvement compared to non-shoppers and high levels of brand consciousness. Recently, Yang and Wu (2007) classified brand consciousness as part of the consumer style for Internet shoppers and is high for both male and female Internet shoppers Therefore, we submit the following:

$\mathbf{H}_{6:}$ Internet shoppers will be more brand conscious than non-shoppers. Price Consciousness

Given their product search capabilities, online shoppers are considered to be well-informed consumers (HOFFMAN; NOVAK, 1997). Smith (2002) notes that consumers readily utilize shopbots that can search the Internet for the best price and value. While this suggests that online shoppers are more likely to be price conscious, Donthu and Garcia (1999) did not find this to be the case in their study. They show that many online buyers are less price-conscious, as they are more concerned with finding products that satisfy their needs rather than look for bargains. Another research effort found that the segment of online shoppers that are focused on utilitarian values such as convenience and time-savings tend to be less price sensitive (SWAMINATHAN; LEPKOWSKA-WHITE; BHARAT, 2003). Hence we propose the following:

$\mathbf{H}_{7:}$ Internet shoppers will be more price conscious than non-shoppers. Attitudes toward Shopping, Direct Marketing and Advertising

Attitudes toward shopping, direct marketing and advertising are linked in the online world. Online shoppers when in "the flow" traverse the web seeking recreation and adventure (HOFFMAN; NOVAK, 1997). To some, shopping is a recreational activity, and recreational shoppers tend to have more positive attitudes toward shopping (BELLENGER; KORGAONKAR, 1980). Donthu and Garcia (1999) found that online shoppers have more positive attitudes towards shopping. Swinyard and Smith (2003) found many consumers view online shopping to be more entertaining than offline shopping.

Internet shoppers are deluged with pop-ups, specials, an assortment of products and buying cites which can overwhelm a consumer. To deal with all of this, consumers 
must have positive attitudes towards such factors in order to withstand the complexity of online shopping. Bellman, Lohse, and Johnson (1999) find that an online buyer tends to enjoy searching and "looking" for information on new products. They have a more positive attitude towards looking around, i.e., shopping for goods and services, and receiving information which will help in their search for the product or service. Online shoppers also tend to have more positive attitudes towards direct marketing and advertising as cyber-shopping provides opportunities to make more purchases (DARIAN, 1987). Ducoffe (1996) found that Internet users have positive attitudes towards advertising and online advertising in particular as they described it as "informative" and "up to date". High usage interactive online-gamers have positive attitudes towards both online advertising and the direct communications that lead them to those services (JONES, 2007). Donthu and Garcia (1999) found that online shoppers had more positive attitudes towards direct marketing and advertising. Therefore we predict:

$\mathbf{H}_{8:}$ Internet shoppers will have more positive attitude toward shopping.

$\mathbf{H}_{9:}$ Internet shoppers will have more positive attitude toward direct marketing.

$\mathbf{H}_{\mathbf{1 0}}$ Internet shoppers will have more positive attitude toward advertising.

\section{Demographics}

In the study by Darian (1987), in-home shoppers tend to have higher levels of income, are above average in education, and are younger than in-store shoppers. Jasper and Lan (1992) found that as age increases, tendency to catalog shop also increases. But with the Internet, the younger cohorts are the "computer generations" and will be more likely to purchase online than older consumers. Online shoppers are younger, possess greater wealth, are better educated, and spend considerable more time on the Internet (SWINYARD; SMITH, 2003; ALLRED; SMITH; SWINYARD, 2006). Thus, we hypothesize:

$\mathbf{H}_{11}$ : Internet shoppers will differ from non-shoppers in (a) age, (b) education, (c) Internet usage, (d) email usage, (e) computer ownership, (f) income and (g) gender.

\section{METHODOLOGY}

The measures used in this were obtained from previous research by Donthu and Gilliland, (1996) and Donthu and Garcia (1999) which looked at shopper profiles and are presented in the Appendix. The measures have been shown to have high reliability and in our study, all measures had coefficient alpha of .70 or higher. The original survey was developed in English, but in China, Bulgaria and Brazil the survey was administered in the native language. The development of the questionnaires followed procedures to assure translational equivalence (KUMAR, 2000). We 
employed a double translation process employing two bilingual translators, where one translated the survey into the respective language and then the second translator reversed the process and translated that survey back into English without seeing the original version. This was followed by a comparison of the translated version with the original English version. Minor discrepancies were reviewed by both translators and revised and the surveys were then pre-tested with experts and practitioners in each of the countries to assure functional and conceptual equivalence of the concepts (KUMAR, 2000). English questionnaires were used in England and New Zealand.

To assure similar data collection procedures, trained researchers were employed in each of the countries. Each researcher was informed of the purpose of the project and on techniques to ensure that the respondent was able to answer the questionnaire. In each country (except the US), the researchers collected responses using a purposive judgment sampling technique at local retailing centers. Respondents were qualified by asking various background questions pertaining to their frequency of e-mail use, frequency of world-wide-web usage and the types of information they typically provide online. They then responded to the questionnaire items concerning the shopper attitudes and motivations, and concluded with various demographic questions. Given the low rates of Internet shoppers in Bulgaria and China, the researchers over sampled the Internet shopper population, thus the percentage of shoppers versus non-shoppers in the sample does not reflect the level of shoppers and non-shoppers in the population. The sample sizes for each country are attached in Table 1.

The hypotheses were tested on country level bases comparing Internet shoppers and non-shoppers. The analysis included one-way ANOVAs with t-tests for continuous measures, and Chi-Square tests for categorical data. The means for Internet shoppers and non-shoppers for each country are seen in Table I. A third column shows the support $(\mathrm{Y})$ or rejection $(\mathrm{N})$ of the specific hypothesis in that sample.

Place Table I about here

\section{RESULTS AND DISCUSSION}

In this study, we extend the work of Donthu and Garcia (1999) by examining Internet shoppers and non-shoppers in five countries in addition to the United States. In doing so our research seeks to expand the domain of our research to a global context. As highlighted earlier, Internet usage and commerce is expected to grow significantly across the world. However, as each part of the world is unique in its social norms, culture, and infrastructure, these differences may cause the profiles of Internet shoppers and non-shoppers to be different worldwide. Therefore it becomes increasingly important to fully understand the differences, similarities, and unique characteristics of Internet shopper and non-shoppers that exist worldwide. The goal of this study was to offer insights into this important question. In our discussion of the results we 
include the findings from Donthu and Garcia (1999) for a broader evaluation of the six countries. The Donthu and Garcia (1999) study suggests that the typical Internet user differs from the Internet shopper. This has profound implications for advertisers and marketers. It suggests that while it is important to understand Internet users, it is also important to profile the Internet shopper, as the two populations are not the same (at least in the United States).

The results of the six-country comparison presented in this paper indicate that across the markets examined, there exists both commonalities and differences between the Internet shopper and the non-shopper. We first document the results relating to the similarities of Internet shoppers in the countries examined in our research. We find a pattern of similarity of results for $\mathrm{H}_{1}, \mathrm{H}_{2}, \mathrm{H}_{5}, \mathrm{H}_{9}, \mathrm{H}_{10}$ and $\mathrm{H}_{11 \mathrm{c}}, \mathrm{H}_{11 \mathrm{e}}, \mathrm{H}_{11 \mathrm{f}}$ and $\mathrm{H}_{11 \mathrm{~g}}$ with all hypotheses being significant in most countries. Internet shoppers across most countries seek convenience through online shopping, are more innovative than non shoppers (except New Zealand), show higher levels of impulsiveness (except New Zealand), have more positive attitudes towards advertising and direct marketing, and have higher incomes. They also exhibit differences in email usage, Internet usage and computer ownership.

$\mathrm{H}_{1}$ stated that Internet shoppers are more convenience seeking than non-shoppers. This hypothesis is supported. Internet shoppers in all the countries examined are similar such that when consumers are looking for convenience they will be more likely to use the Internet for shopping. This is in accordance with prior research has found that when consumers look for convenience, the Internet becomes the retail channel of choice (MATHWICK; MALHOTRA; RIGDON, 2000). $\mathrm{H}_{2}$ was also supported in our research. Internet shoppers in the countries examined (except New Zealand) were more innovative than non-shoppers. The extant research has conceptualized consumer innovativeness on the Internet to be more 'domain specific' by the virtue of identifiable characteristics (e.g. opinion leadership, etc.) and actual acquisitions of new information, ideas, and products (MIDGLEY; DOWLING, 1978). Domainspecific innovativeness reflects personal innovativeness and is conceptualized as the degree and speed of adoption of innovation by an individual. In a marketing context, the construct has been measured via purchase intentions and opinions for certain new products, the number of new products owned, and the relative time of adoption for particular new products, and is usually applied to domain-specific products and services (LASSAR; MANOLIS; LASSAR, 2005). Our findings in the countries examined show that consumers who are more innovative are more likely to use the Internet for shopping while those that are less innovative are less likely to do so. This is in line with a steam of research, which shows that those who have knowledge of and opinions about a particular domain, and are willing to share their opinions with others are more likely to be adopters and users of commercial innovations (ROGERS, 1995). 
$\mathrm{H}_{3}$ was also supported in our research. Internet shoppers in all the countries (except New Zealand) showed higher levels of impulsiveness than non-shoppers. $\mathrm{H}_{9}$ and $\mathrm{H}_{10}$ hypothesized relations between attitudes of Internet shoppers towards direct marketing and advertising respectively. Both these hypotheses were supported. Internet shoppers, across all the countries examined, were found to be more receptive to both direct marketing and advertising when compared with non-shoppers. Finally $\mathrm{H}_{11 \mathrm{c}}, \mathrm{H}_{11 \mathrm{e}}, \mathrm{H}_{11 \mathrm{f}}$, and $\mathrm{H}_{11 \mathrm{~g}}$ were concerned with differences between Internet shoppers and non-shoppers with regard to demographic variables. As expected, in all countries (expect the U.S. where data was not available) Internet shoppers' income, email and Internet usage, and computer ownership was significantly more than that of non-shoppers. These findings underscore the important role of demographic variables in Internet shopping behavior in an international context. The general pattern of findings highlights that Internet shoppers exhibit similarities globally when compared with non-shoppers.

However, there were certain differences between Internet shoppers in the different countries as well. Internet shoppers in the U.S., New Zealand, England and Brazil were more risk averse $\left(\mathrm{H}_{3}\right)$ than non-shoppers, but no differences was found for the Bulgarian or Chinese samples. No significant differences were found between Internet shoppers and non-shoppers across most of the countries examined with regard to variety seeking behavior except in the U.S., and Bulgaria. $\mathrm{H}_{6}$ hypothesized that Internet shoppers would be more brand conscious than non-shoppers. Internet shoppers in Bulgaria and China are more brand conscious than non-shoppers, while no significant differences were found between the 2 groups in the U.S., New Zealand, England and Brazil. Pricing concerns were significantly different for Internet shoppers and non-shoppers in the Brazilian, Chinese, New Zealand, and England samples but not for the US and Bulgaria $\left(\mathrm{H}_{7}\right)$. Variety seeking behavior was the complete opposite of price consciousness. Internet shoppers in the Brazil, Bulgaria, New Zealand, and England were seen to exhibit more positive attitudes towards shopping than nonshoppers, but not in the U.S., and China, $\left(\mathrm{H}_{8}\right)$. There were significant differences of age $\left(\mathrm{H}_{11 \mathrm{a}}\right)$ between Internet shoppers and non-shoppers in the U.S. and Brazil but not in any of the other countries. Internet shoppers tend to be better educated than non-shoppers in Bulgaria, China, and England but not in the U.S., Brazil, and New Zealand $\left(\mathrm{H}_{11 \mathrm{~b}}\right)$. No differences were found with regard to the gender variable in all the countries except in New Zealand $\left(\mathrm{H}_{11 \mathrm{~d}}\right)$.

\section{MANAGERIAL IMPLICATIONS}

The findings of this study provide interesting insights for marketing managers interested in international Internet commerce. As the Internet usage grows worldwide, managers need to understand their consumers and the distinguishing characteristics 
between Internet shoppers and non-shoppers globally. This distinction will enable managers to tailor the online experience in ways that will actually make Internet shoppers purchase and repurchase from their websites while enabling these websites to appeal to non-shoppers as well. An additional goal of such an understanding should be to encourage non-shoppers to shop online.

The results from our study imply that a global approach to online marketing is not optimal. A lack of understanding of consumer preferences can cause a successful strategy in one country to fail in another (LYNCH; BECK, 2001). An eye toward customized strategies for each market may be required in order to effectively achieve desired goals. Companies based in the United States may need to change their strategies to reach Internet shoppers and non-shoppers around the world. Even countries that are culturally similar to the U.S. (e.g. England) seem to have a somewhat different Internet shopper profile. Our study shows that while Internet shoppers worldwide are similar with regard to certain characteristics, they differ on others. Accordingly companies competing globally on the Internet would benefit by adopting regional strategies that capitalize on the unique preferences of specific markets (LYNCH; KENT; SRINIVASAN, 2001).

The findings of our study have important implications for website design. Localizing websites beyond translations and paying attention to local conventions, time and date formats, addresses and phone numbers, layout and orientation of webpages, units of measurement, colors and aesthetics are important elements of a successful international e-commerce strategy (SINGH; FURRER; OSTINELLI, 2004). However, creating a large number of mirror sites around the globe and tailoring the content of each site to the global region might be impractical and costly for some companies. For such companies easier alternatives might be to create a smaller set of regional sites or partnering with locally produced portals that are very culturally specific and are popular access points to the web. This makes an Internet strategy viable to companies of different sizes.

Our research shows that convenience is more important to Internet shoppers than non-shoppers. Marketers need to focus on making the online purchasing process easier in order to encourage repeat purchases among Internet shoppers. Marketers can also focus on the benefits of staying online, social networking, researching products and services and an overall easier shopping experience (IYER; EASTMAN, 2006). Additionally, marketers can emphasize the convenience of shopping from home as opposed to physically going to a store. The Internet can be thus positioned as a tool that can make shopping easier. Our research also shows that Internet shoppers exhibit higher levels of impulsiveness than non-shoppers. Research using the Technology Acceptance Model (TAM) has found positive relationships between consumer impulsiveness and purchase intention, meaning that more impulsive consumers tend to make 
more purchases online (ZHANG; PRYBUTOK; KOH, 2006). Accordingly companies can look at using online promotions and discount pricing to target the impulsiveness of Internet shoppers by stimulating more spontaneous purchasing activity.

As e-commerce has grown so have concerns of online consumer privacy, the protection of consumer information and the intrusive nature of online communications. Our results show that Internet consumers are more receptive to advertising and direct marketing. Managers can use this knowledge to target the Internet shoppers knowing that they are more likely to be receptive to highly targeted marketing communications. The mixed results for demographic variables such as age, education, and gender imply that demographic variables might not play the same role in every country. While Internet shoppers are distinguished from non-shoppers by virtue of income, computer ownership, and email and Internet usage, they are not different from non-shoppers with regard to education, age and gender in most of the countries examined. This is in contrast to findings in prior research where Internet shoppers in the U.S. were found to be primarily young, educated, and male. While not tested in this paper, this could be related to the spread of the Internet worldwide. A higher level of familiarity with the Internet may lead to a profile of the Internet shopper that is similar to mainstream buyers, i.e. the Internet might not be the preserve of a specific demographic. For marketers this information has implications for product categories offered online and expands the categories of products that can be offered online globally. Further managers need to exercise caution in using only demographic variables to target online shoppers.

\section{FUTURE RESEARCH AND LIMTATIONS}

Research in the area of international business was influential in that it explored regional similarities and differences that contributed knowledge leading to effective worldwide marketing strategies. The new frontier in this effort is to more fully understand Internet commerce across the globe. The current study sought to shed light on the differences and similarities that appear to exist between groups of Internet shopper profiles. While this study yielded interesting results, it is clear there is much work to be done in this area.

One undertaking worth the effort would be the development of profiles of the Internet shopper utilizing a wide variety of comparison points. While profiles of the Internet user and shopper are emerging (ex. BRENGMANA et al., 2005; ROHM; SWAMINATHAN, 2004), global profiles have yet to be fully explored. For example, it would be interesting to understand if cybershopper segments identified in the U.S. are found in other countries. A future study that would identify and compare profiles across markets would be of value. A future examination that attempts to link the cultural 
characteristics of consumers with their Internet related behaviors would also greatly add to our understanding in this area. Additional research can also look at the roles of product categories in distinguishing between Internet shoppers and non-shoppers.

Our study has several of the limitations of survey research. Second, our use of purposive sampling reduces objectivity. Future research could look at sampling a broader segment of the population to increase generalizability. The number of countries used in the study is limited primarily due to a lack of access so whether the findings are generalizable to other countries are unclear. Additional research could attempt to replicate our research in other nations to see if the results in our study hold in other contexts and cultures.

\section{REFERENCES}

A.C NIELSEN, Global Online Shopping Habits. October, 2005.

ALLRED, Chad R.; SMITH Scott M.; SWINYARD. William R. E-Shopping Lovers and Fearful Conservatives: A Market Segmentation Analysis. International Journal of Retail \& Distribution Management, v.34, n.4/5, p. 308-333, 2006

BELLENGER, Danny; KORGAONKAR, Pradeep. Profiling the Recreational Shopper, Journal of Retailing, v.56, n. 4, p. 77-92, 1980.

BELLMAN, Steven; LOHSE, Gerald L.; JOHNSON, Eric J. Predictors of Online Buying Behavior, Source: Communications of the ACM, v.42, n. 12, p. 32-38, 1999.

BRENGMANA, Malaika et al. Segmenting Internet Shoppers based on their WebUsage-Related Lifestyle: A Cross-Cultural Validation, Journal of Business Research, v.58, n. 1, p. $79-88,2005$.

BUSINESSWEEK Online (2006), Internet population hits new high in U.S. http:// www.businessweek.com/ap/financialnews/D8H7UK580.htm.

COMPUTER INDUSTRY ALMANAC. Released report January 4, 2006.

DARIAN, Jean C.In-home Shopping: Are there Consumer Segments? Journal of Retailing, v. 63, n. 2, p.163-186, 1987.

DATAFOLHA. Top of Mind Internet, Sao Paulo, May 20. 2007, http://datafolha. folha. uol.com.br/po/ver_po.php?session=455\#, 2005. 
DELLNER, Tom. European e-commerce, Electronic Retailer, www.electronicretailermag.com /info/0607_euro.html, 2007.

DONTHU, Naveen; GARCIAAdriana. The Internet Shopper, Journal of Advertising Research, v. 39, n. 3, p. 52-58, 1999.

DONTHU, Naveen; GILLILAND, David. The Infomercial Shopper, Journal of Advertising Research, v. 36, n. 2, p. 69-76, 1996.

DOOLIN, Bill et al. Perceived Risk, the Internet Shopping Experience and Online Purchasing Behavior: A New Zealand Perspective, Journal of Global Information Management, v. 3, n.2, p.66-88, 2005.

DUBELAAR, Chris, JEVONS, Colin; PARKER, Lukas.Personal Information Privacy and Shopping Behavior on the Internet, Journal of Asia Pacific Marketing, v.2, n.1, p. 65-71, 2003.

DUCOFFE, Robert H. Advertising Value and Advertising on the Web, Journal of Advertising Research,v. 36, n. 5, p. 21-35, 1996.

EMARKETER.com, 2007

EASTLICK, Mary A.; FEINBERG, Richard A. Shopping Motives for Mail Catalog Shopping Journal of Business Research, v. 45, n. 3, p.281-290, 1999.

GERMANY: ONLINE OVERVIEW; EMARKETER. Disponível em: $<$ http://www. emarketer.com/Reports/Al1/Emarketer_2000461.aspx?src=report_head_info_siteseaearch>. 2007.

GIRARD, Tulay; KORGAONKAR, Pradeep; SILVERBLATT, Ronnie. Relationship of Type of Product, Shopping Orientations, and Demographics with Preference for Shopping on The Internet, Journal of Business and Psychology, v.18, n.1, p.101-120, 2003.

GOLDSMITH, Ronald E.; HOFACKER, Charles F.Measuring Consumer Innovativeness, Journal of the Academy of Marketing Science, v.19, n.3, p.209-221, 1991.

Goldsmith, Ronald E.; FLYNN,Lisa R. Psychological and Behavioral Drivers of Online Clothing Purchase, Journal of Fashion Marketing and Management, v. 8, n. 1, p. 84-95, 2004. 
A six-country comparison of the internet shopper profile

HOFFMAN, Donna L.; NOVAK, Thomas P.A. New Marketing Paradigm for Electronic Commerce, The Information Society, 13, Jan-Mar, p. 43-54, 1997.

HUANGA, Wen-Hsien; KUAIB, Liang. The In-flight shopper, Journal of Air Transport Management, v. 12, n. 4, p. 207-211, 2006.

INTERNETWORLDSTATS.com. Disponível em: $<$ http://www.Internetworldstats. com/stats.htm>.

IYER, Rajesh; EASTMAN, Jacqueline K. The Elderly and Their Attitudes Toward the Internet: The Impact on Internet Use, Purchase, and Comparison Shopping, The Journal of Marketing Theory and Practice, v. 14, n.1, p. 57-67, set. 2004.

JASPER, Cynthia. R.; LAN, Pi-Nan R. Apparel Catalog Patronage: Demographic, Lifestyle, and Motivational Factors, Psychology and Marketing, v. 9, n. 4, p.275-296, 1992.

JONES, Gareth. Gamers Embrace the Message, Marketing, Sept. 5, 16, 2007.

KAHN, Barbara E.; ISEN, Alice M. The Influence of Positive Affect on VarietySeeking among Safe, Enjoyable Products, Journal of Consumer Research, v.20, n. 2, p. 257-270, 1993.

KIM, Soyoung; LEE, Yuri. Global Online Marketplace: A Cross-Cultural Comparison of Website Quality, International Journal of Consumer Studies, v.30, n. 6, p. 533-543, 2006.

KOLSAKER, Ailsa; LEE-KELlEY, Liz; PUI, Ching Choy. The Reluctant Hong Kong Consumer: Purchasing Travel Online, International Journal of Consumer Studies, v.28, n.3, p.295-304, 2004.

KORGOANKAR, Pradeep K.; WOLIN, Lori D. A Multivariate Analysis of Web Usage, Journal of Advertising, v.39, n. 2, p. 53-68, 1999.

KUMAR, V. International Marketing Research. Upper Saddle River, NJ: Prentice Hall, 2000;

LASSAR, Walfried M.; MANOLIS, Chris; LASSAR, Sharon S. The Relationship between Consumer Innovativeness, Personal Characteristics, and 
Online Banking Adoption, International Journal of Bank Marketing, v. 23, n. 2, p. 176-99, 2005.

LYNCH, Patrick D.; BECK, John C.Profiles of Internet Buyers in 20 Countries: Evidence for Region-Specific Strategies, Journal of International Business Studies, v.32, n. 4, p. 725-769, 2001.

LYNCH, Patrick D.; KENT, Robert J.; SRINIVASAN, Srini S. The Global Internet Shopper: Evidence from Shopping Tasks in Twelve Countries, Journal of Advertising Research, v.41, n. 3, p. 15-23, 2001.

MAHMOOD, M Adam; BAGCHI Kallol; FORD Timothy C. Online Shopping Behavior: Cross-country Empirical Research. Ergonomics, v.47, n.5, p. 469-482, 2004.

MATHWICKA, Charla; MALHOTRA, Naresh; RIGDON, Edward. Experiential Value: Conceptualization, Measurement and Application in the Catalog and Internet Shopping Environment, Journal of Retailing, v.77, n.1, p. 39-56, 2001.

MIDGLEY, David F.; DOWLING, Grahame R. Innovativeness: The Concept and Its Measurement, Journal of Consumer Research, v. 4, n. 4, p. 229-235, 1978.

MOE, Wendy W. FADER, Peter S. Uncovering Patterns in Cybershopping. California Management Review, v. 43, n. 4, p. 106-117, 2001.

Park Cheoul; JUN, Jong-Kun. A Cross-Cultural Comparison of Internet Buying Behavior, International Marketing Review, v.20, n.5, p. 534-553, 2003.

PARK, Jihye; STOEL, Leslie. Effect of Brand Familiarity, Experience, and Information on Online Apparel Purchase, International Journal of Retail \& Distribution Management, v. 33, n. 2, p. 148-160, 2005.

PECHTL, Hans.Adoption of Online Shopping by German Grocery Shoppers", The International Review of Retail, Distribution and Consumer Research, v.3, n.2, p. 145-159, 2003.

RATNER, Rebecca K.; KAHN, Barbara E. The Impact of Private versus Public Consumption on Variety-Seeking Behavior, Journal of Consumer Research, v. 29, n. 2, p. 246-257, 2002. 
Daniel. Choosing Less-Preferred Experiences for the Sake of Variety, Journal of Consumer Research, v. 26, n. 1, p. 1-15, 1999.

ROGERS, Everett .M. The Diffusion of Innovations, 4th ed., The Free Press, New York, NY, 1995.

ROHM, Andy; SWAMINATHAN, Vanitha. A Typology of Online Shoppers Based on Shopping Motivations, Journal of Business Research, v.57, n.7, p. 748-757, 2004.

SEO, Jung-Im. Internet purchasing decision behavior and product involvement, $: \mathrm{PhD}$ Dissertation, UMI: 3180921, 2005.

SHANGHAI DAILY. Survey Tells Something About Chinese Internet Users, Available at. (http://210.77.134.148/pls/wcm/Show_Text?info_id=744\&p_ qry=Internet). 2001.

SHIM, Soyeon; GEHRT, Kenneth C. Hispanic and Native American Adolescents: An Exploratory Study of Their Approach to Shopping, Journal of Retailing, v. 72, n. 3, p. 307-324, 1996.

SINGH, Nitish; FURRER Olivier; OSTINELLI Massimiliano.To Localize or to Standardize on the Web: Empirical Evidence from Italy, India, Netherlands, Spain, and Switzerland, Multinational Business Review, v.12, n. 1, p. 69-87, 2004.

SMITH, Michael. D. The Impact of Shopbots on Electronic Markets, Journal of the Academy of Marketing Science, v. 30, n. 4, p. 446-454, 2002.

SOOPRAMANIEN, Didier G.R.; ROBERTSON Alastair. Adoption and Usage of Online Shopping: An Empirical Analysis of the Characteristics of "Buyers", "Browsers", and "Non-Internet Shoppers, Journal of Retailing and Consumer Services, v. 14, , p.73-82, 2007.

SPROLES, George B.;KENDALL, Elizabeth L. A Methodology for Profiling Consumers' Decision-Making Styles, Journal of Consumer Affairs, v. 20, n. 2, p.267-279. 1986.

SRI International. Exploring the World Wide Web Population's Other Half. http:// future.sri.com/. 1995. 
SWAMINATHAN, Vanitha; LEPKOWSKA-WHITE; Elzbieta; BHARAT, P. Rao. The Internet and Consumer Buying Behavior: A Research Framework and Analysis in Current Topics in E-Commerce (ed.) Charles Steinfield, Indiana: Purdue University Press, p. 64-84, 2003.

SWINYARD, William R.; SMITH, Scott M. Why People (don't) Shop Online: A Llifestyle Study of the Internet Consumer, Psychology \& Marketing, v. 20, n. 7, p. 567-598, 2003.

TAN, Soo J. Strategies for Reducing Consumers' Risk Aversion in Internet Shopping, The Journal of Consumer Marketing, v.16, n. 2, p.163-180, 1999.

WOOD, Michael. Discretionary Unplanned Buying in Consumer Society, Journal of Consumer Behaviour, v. 4, n. 4, p. 268-281, 2005.

YANG, Chyan; WU, Chia-Chun. Gender and Internet Consumers' Decision-Making. CyberPsychology \& Behavior, v. 10, n. 1, p. 86-91, 2007.

ZHANG, Xiaoni; PRYBUTOK, Victor R.; KOH, Chang E. The Role of Impulsiveness in a TAM-Based Online Purchasing Behavior Model, Information Resources Management Journal, v. 19, n. 2, p. 54-68, 2006.

\section{APPENDIX}

\section{List of Measures Used in Study}

\section{$\underline{\text { Risk Aversion }}$}

I would rather be safe than sorry.

I want to be sure, before I purchase anything

I avoid risky things

\section{Innovativeness}

I like to take chances

I like to experiment with new ways of doing things

New products are usually gimmicks

\section{Brand Consciousness}

I usually purchase brand name products 
Store brands are of poor quality

All brands are about the same

\section{Price Consciousness}

I usually purchase the cheapest item

I usually purchase items on sale only

I often find myself checking prices

A person can save a lot by shopping for bargains

\section{Importance of Convenience}

I hate to spend time gathering information on products

I do not like complicated things

It is convenient to shop from home

\section{Variety Seeking}

I like to try different things

I like a great deal of variety

I like new and different styles

\section{Impulsiveness}

I often make unplanned purchases

I like to purchase things on a whim

I think twice before committing myself

I always stick to my shopping lists

\section{Attitude towards Advertising}

Advertisements provide useful information

I think that advertisements are often deceptive

I usually do not pay any attention to advertisements

Attitude towards Shopping

Shopping is fun

I get a real high from shopping

Buying things makes me happy

\section{Attitude towards Direct Marketing}

Phone solicitations are an invasion of my privacy

I enjoy receiving junk mail

I often use catalogues to shop for products 
Thomas G. Brashear • Vishal Kashyap • Michael D. Musante • Naveen Donthu

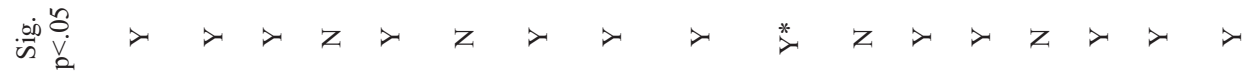

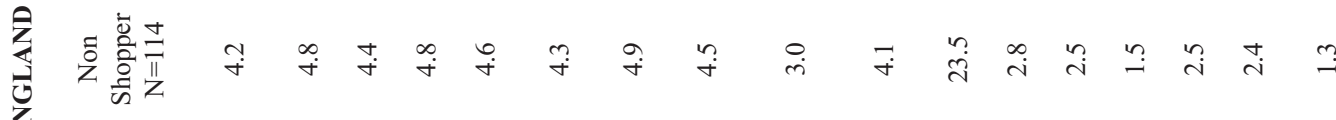

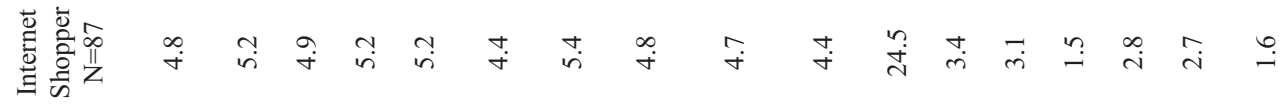

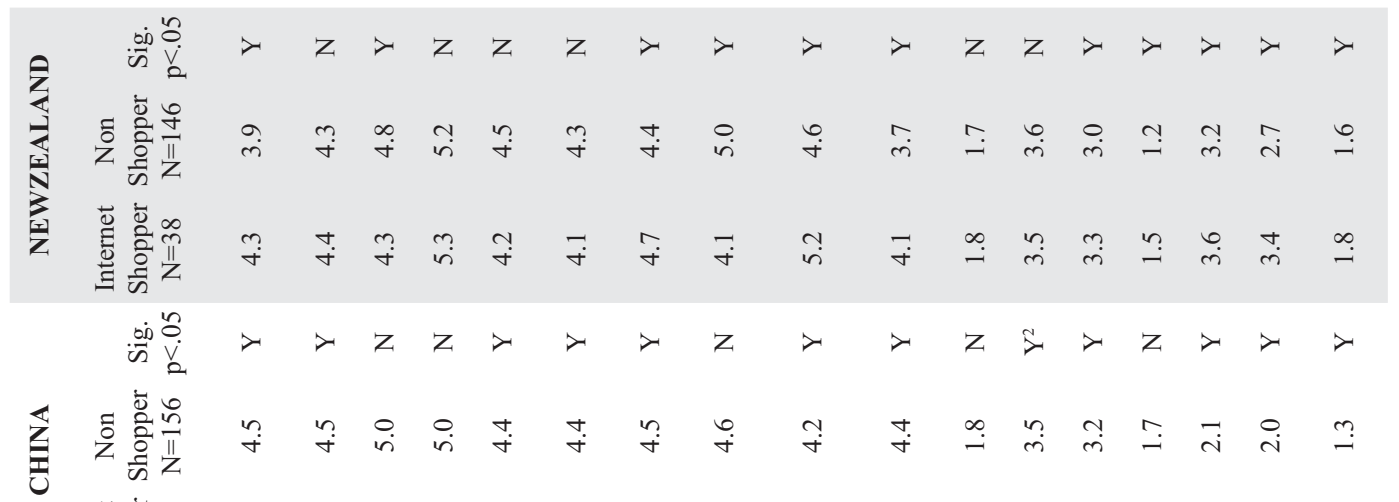

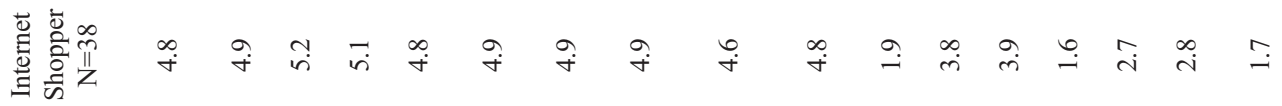

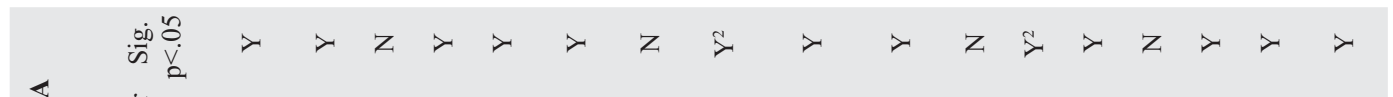
选

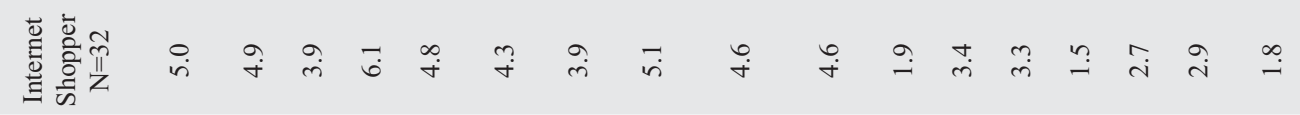

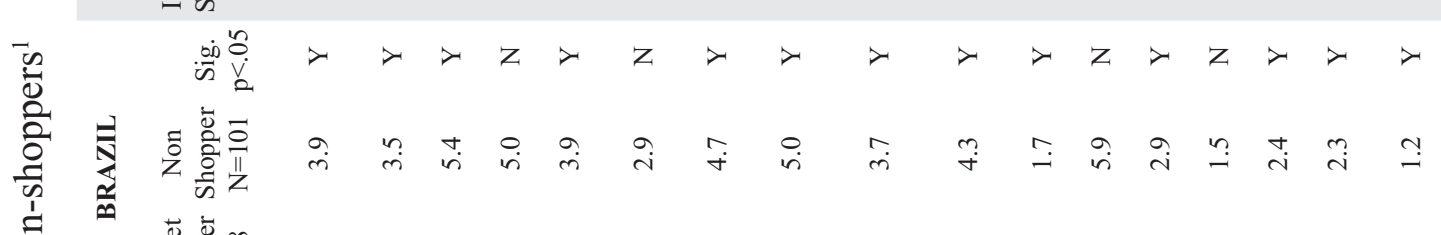

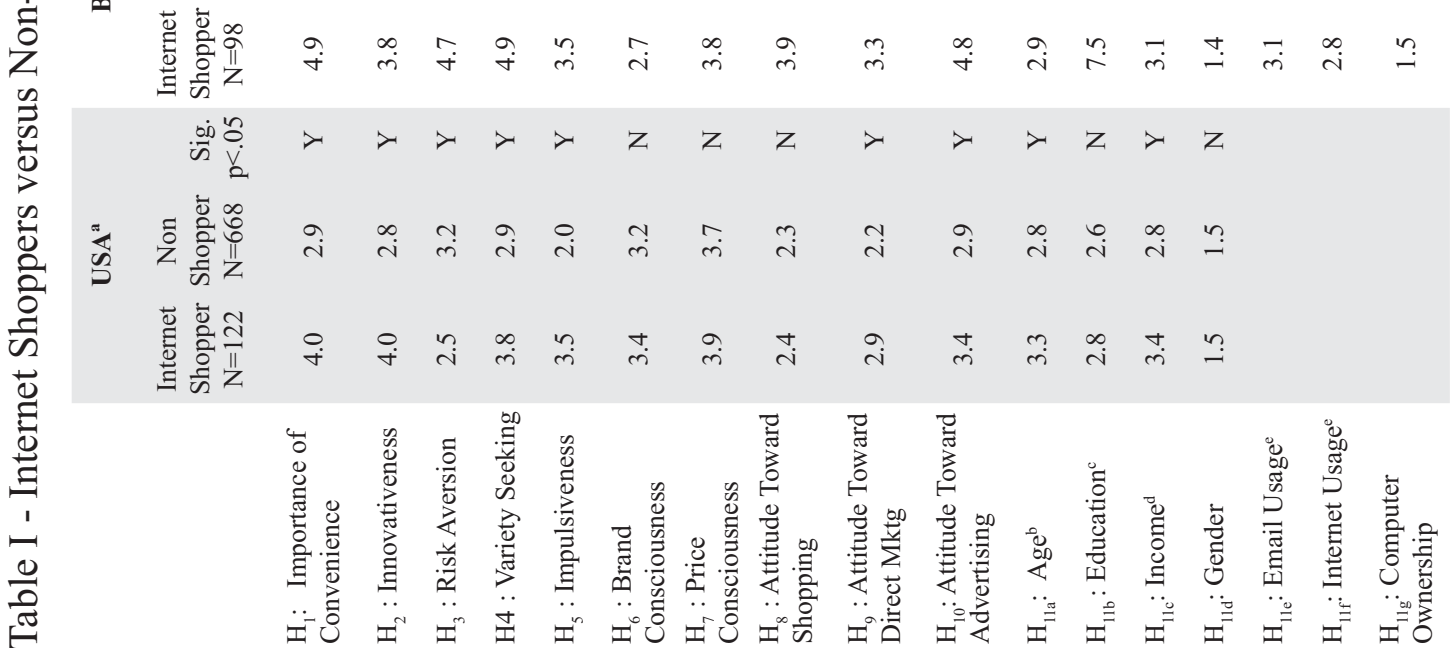


A six-country comparison of the internet shopper profile

1. Significant at $\mathrm{p}<.05$.

2. Significant at $\mathrm{p}<.10$.

a. From Donthu and Garcia (1999)

b. Age ranges $1=0-19,2=20-35,3=36-50,4=51-65,5=65+$

c. Education categories vary by country but follow a ranking of primary to postgraduate.

d. For Brazil, Bulgaria, China, and New Zealand, income categories were: $1=$ Much worse off than colleagues, $2=$ Worse off than colleagues, $3=$ Same as colleagues, $4=$ Better off than colleagues, 5

$=$ Much better off than colleagues.

e. Usage rated on: $1=$ Never, $2=$ Once in while, $3=$ Once a day, $4=$ More than once a day. 